\title{
Immunogenetics of trophoblastic tumours
}

\author{
SYLVIA D. LAWLER
}

\begin{abstract}
From the Department of Cytogenetics and Immunology, Division of Medicine, Institute of Cancer Research and the Royal Marsden Hospital, London
\end{abstract}

The fetus is an allograft foreign to the mother by the hemizygous set of paternal alleles. In a randomly mating population the mother may be incompatible with the fetus at any locus and the chance of incompatibility is increased according to the number of alleles at that locus.

The persistence of the normal human fetal allograft is a puzzle that continues to intrigue biologists. The immunobiology of the trophoblast was debated at length at a symposium held in Cambridge in 1973. In a preface to the proceedings the editors (Edwards, et al, 1975) ventured their personal opinion that 'the properties of the trophoblast as a natural filter currently offer the most critical single explanation for fetal survival'. To search for a single explanation of such complex biological interactions as those involved in the fetomaternal relationship is perhaps rather ambitious. The problem of the persistence of trophoblast-natural, invasive, or malignant- must be regarded as a sequel of maternal conditioning to the normal products of conception. This may affect her role as host to any supervening malignantly transformed trophoblast.

\section{Major Histocompatibility Systems}

\section{THE HLA SYSTEM}

It is probable that each species has a major histocompatibility complex and in man this is called HLA. It is a system with a high degree of polymorphism with a wide tissue distribution of some of the antigenic determinants and a more limited expression of others. There are four loci with polymorphic variants identifiable in Caucasians: $A(12)$, $\mathrm{B}(17), \mathrm{C}(5)$ and $\mathrm{D}(6)$. The specificities given in table $\mathrm{I}$ are designated according to the WHO-Iuis terminology (Histocompatibility Testing, 1975). The A, B and C locus antigens are detected serologically by a microcytotoxicity test on lymphocytes. The D locus antigens are detected by the mixed lymphocyte culture method using homozygous cells from donors of known $D$ locus types as standard stimulating cells. The A, B and C locus antigens are expressed on both $\mathrm{T}$ and $\mathrm{B}$ lymphocytes, the $\mathrm{D}$ locus antigens are certainly present on B lymphocytes but the situation with regard to their presence on $\mathrm{T}$ lymphocytes is unresolved. The next histocompatibility workshop, the seventh, is to be concerned with the detection of determinants specific for B lymphocytes that are absent from $T$ lymphocytes. These are envisaged as the human homologue of the $I^{a}$ specificities described in other species (Sachs and Cone, 1973).

The major histocompatibility complex is inherited as a genetic unit, the haplotype. Recombination of about $1 \%$ is known to occur between the $A$ and $B$ loci and it is likely to occur with the same order of frequency at the other loci. The position of the loci on the chromosome is in the alignment A, C, B, D.

THE ABO BLOOD GROUP SYSTEM

In the context of histocompatibility the role of the ABO system must also be considered even though its role in tissue transplantation appears to be subordinate to that of the HLA system.

\section{Histocompatibility and Reproduction}

Consideration will now be given to the relevance of the HLA and ABO systems in the processes preceding the possibility of persistence of trophoblast, namely, properties of gametes, fertilization, and the maintenance and termination of pregnancies.

\section{FERTILITY}

The products of the main histocompatibility systems in man are expressed on spermatozoa. Haploid expression of HLA antigens of the A and B loci has been demonstrated by Fellous and Dausset (1970), and later Halim et al (1975) showed that the haplotype was expressed on the heads of the spermatozoa. Levis et al (1974) showed that human spermatozoa stimulated allogeneic lymphocytes in culture and suggested the use of this method in one-way mixed lymphocyte culture tests. The value of the technique has been confirmed by Halim and Festenstein (1975) who have demonstrated the haploid expression of D locus antigens on spermatozoa.

These observations present a mechanism for the selection of spermatozoa for fertilization through 


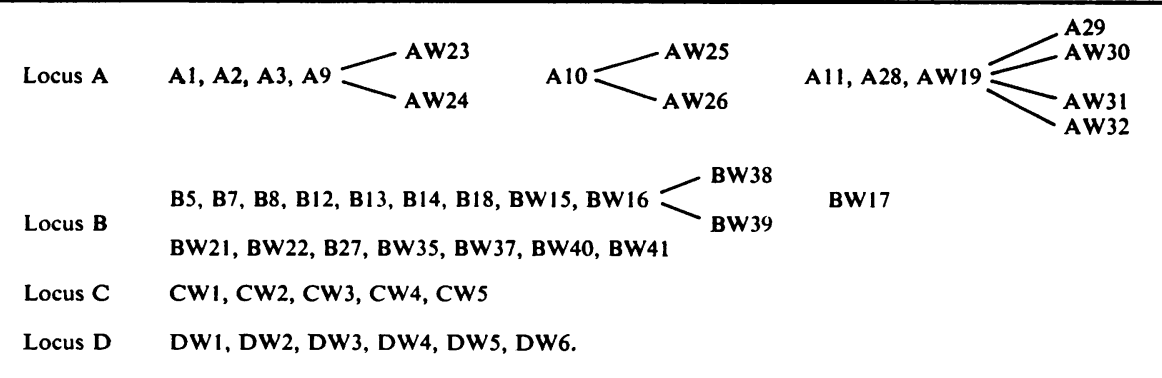

Table I The HLA system ( $W H O$ nomenclature, 1975) ${ }^{1}$

'This system is for antigens detectable in Caucasians and antigens peculiar to other racial groups are excluded.

the HLA system. There is little evidence of this in outbreeding populations. Amos (1974) has studied the problem in the Amish who are an inbred population with a tendency to large families. An attempt to demonstrate a selective advantage of a particular haplotype gave barely significant results even when families with six sibs were analysed. However there was some evidence that fewer of the expected genotypes were expressed, with increasing parity. Some indication of selection pressures exerted through HLA in a hybrid group was obtained by studying the offspring of particular mixed racial groups but, again, the effect was far from definitive.

The situation with regard to the expression of $\mathrm{ABO}$ antigens on spermatozoa is less clear cut than in the case of the HLA system. It has been known for many years that $A$ and $B$ antigens can be detected on isolated human spermatozoa (Landsteiner and Levine, 1926) but at that time no account was taken of $\mathrm{ABH}$ secretor status. The presence of $\mathrm{ABH}$ substances in the seminal fluid of secretors raises the question whether when these substances are detected on spermatozoa they are intrinsic or merely absorbed from the seminal fluid. The A and B antigens were found by Edwards et al (1964) to be present on the spermatozoa of secretors and absent from those of non-secretors, suggesting that the antigens were present because of absorption. On the other hand, Gullbring (1957) had presented evidence in favour of haploid expression by demonstrating A and B antigens on separate spermatozoa but he did not state secretor status. Haploid expression on the spermatozoa of secretors has been confirmed by Kerék (1974) who obtained negative results in the case of a group A non-secretor. If haploid expression on the spermatozoa of secretors only is a genetic effect, then this could be due to a similar genetic interaction taking place between the $\mathrm{ABH}$ and secretor systems in the haploid state as occurs in the diploid. Furthermore the observation that some of the spermatozoa of $\mathrm{AB}$ donors express neither antigen (Kerék, 1974) might be due to the fact that the donor is heterozygous at the secretor locus.

There is a considerable volume of literature concerning the $\mathrm{ABO}$ groups and selection of offspring, but little evidence of real effect.

\section{ABORTION}

Recent work of Alberman et al (1975) shows clearly that there are two sorts of abortion, those due to a faulty fetus and those due to rejection by the mother. In a series including early and late abortions chromosomal abnormality of the fetus was detected in $28.2 \%$ (Alberman et al, 1975) and a frequency of $60.4 \%$ was obtained by Boué et al (1973) for abortions at 12 weeks or less. Abortions occurring during midtrimester are likely to include a few hydatidiform moles.

There is no solid evidence of the effect of the HLA system in relation to abortion. The combined use of a cytogenetic and immunological approach presents a way of defining the causes of abortion as due to fetal or maternal faults or fetomaternal interactions. Lauritsen et al (1975) have concluded that ABO incompatibility between mother and fetus is likely to be a cause of early abortions, but almost exclusively when the fetus has normal chromosomes.

\section{HLA Antibodies and Pregnancy}

In an $\mathrm{ABO}$ incompatible pregnancy maternal antibody against fetal red cells is preformed. The effect of the pregnancy is to alter the character of the antibody which is part of the process which may culminate in haemolytic disease of the newborn due to antibodies of the ABO system. The important biological interaction of the $\mathrm{ABO}$ and Rhesus system is a model of interplay between different genetic systems (Levine, 1943). 
Antibodies against A, B, C and locus antigens and the predicted ' $\mathrm{I}^{\mathrm{a}}$ ' antibodies can be produced in pregnant women as a consequence of immunization by the fetus. There is no doubt that immunization against HLA antigens can occur in normal primiparous women and it has been assumed that the passage of fetal lymphocytes into the maternal circulation is the mechanism, but this is not necessarily the only route.

Since 1970, patients of Professor K. D. Bagshawe at Charing Cross Hospital, London, undergoing treatment for persistent trophoblastic disease have been tested sequentially for the presence of HLA antibodies. These patients include 46 who had a hydatidiform mole in the first pregnancy. Fifteen of these patients had never been transfused whilst the remainder had received blood before being tested for antibodies. (The transfusion of a pregnant woman may boost antibody formation against fetal antigens, or broaden the specificity, or result in production of antibodies against antigens in the donor's blood that are not necessarily present in that of the husband.) The results of testing these patients for the presence of cytotoxic antibodies against the lymphocytes of their husbands and a panel of normal donors are shown in table II. In the case of the non-transfused patients the specificity of the antibody corresponded to an antigen of the spouse, but amongst the transfused patients in six cases the antibody formation had been provoked by the transfusions and not by the conceptus. If these cases are omitted from the antibody producers then 18 out of the 40 patients had been immunized by a pregnancy with a hydatidiform mole, representing at least twice the frequency of immunization in primigravida, which has been given as $20 \%$ at 32 weeks (Bodmer, 1973).

It would appear that molar pregnancies are more immunogenic than normal ones since more than half the non-transfused patients had formed antibodies specific for the husband's HLA antigens. This was strong evidence for immunogenicity of trophoblastic tissue or its exported or breakdown products, and would support the claims of Loke et al (1971) that HLA antigens can be demonstrated on trophoblast in vitro. Furthermore, it suggests that it may be the trophoblast that is immunogenic in normal pregnancies because it provides a richer and more

\begin{tabular}{lcc}
\hline & Antibody + & Antibody - \\
\hline Patient not transfused & 6 & 9 \\
Patient transfused & 18 & 13
\end{tabular}

Table II HLA Antibodies in patients' sera following a first pregnancy with a hydatidiform mole (1970-1974) readily available source of immunogen than the occasional leak of fetal lymphocytes during a pregnancy. Fetal lymphocytes have not been detected with certainty in maternal blood, but this could be due to technical difficulties in detecting minor populations of the order of 1:1500 (Adenolfi, 1975).

When the pregnancy that precedes a choriocarcinoma is a term birth it is reasonable to assume that the tumour is isogenic with the child. Evidence in favour of this idea has been obtained by studying the specificities of the antibodies produced by patients with choriocarcinoma who have had but one pregnancy.

The association of a previous full-term pregnancy with the development of choriocarcinoma is most clearly demonstrated in those cases in which there has been only one conceptus. Amongst the series of patients tested between 1969 and 1974 were 36 whose husbands and children were available for typing. The ABO groups and HLA haplotypes of these families are given in table III in which only the child antecedent to the choriocarcinoma is listed. Twenty-five of the patients listed in table III were tested for HLA antibodies while they were under treatment. If a patient becomes immunized against HLA antigens during pregnancy these antibodies remain detectable for variable lengths of time after parturition but they are usually not detectable between pregnancies. In our laboratory we occasionally detect HLA antibodies specific for the husband's antigen many years after the last pregnancy. Similarly if the patients who are treated for trophoblastic disease form HLA antibodies these usually, but not always, persist during treatment but they disappear at various intervals after the tumour has been eliminated by the therapy as assessed by HCG levels and clinical criteria.

Nineteen of the 25 patients shown in table IV had formed HLA antibodies. All of these antibodies reacted with HLA antigens present on the cells of the husband, and, except in one case, the patient's serum also reacted with the cells of the antecedent child. The exceptional case, in which the antibody reacted only with the cells of the husband, can be explained by immunization by transfusion against antigens of the paternal haplotype not inherited by the antecedent child. The proportion of antibody producers is high, which is undoubtedly due to the fact that most of the patients had also been transfused before being tested for HLA antibodies. It has been shown that patients with trophoblastic neoplasia can be divided into responders and nonresponders as far as making antibodies against $\mathrm{A}$ and B locus antigens is concerned (Lawler, 1973). The primiparous patients included one who had not 


\begin{tabular}{|c|c|c|c|c|c|c|c|c|c|c|c|}
\hline \multirow{2}{*}{\multicolumn{2}{|c|}{$\begin{array}{l}\text { Case } \\
\text { No. }\end{array}$}} & \multirow{2}{*}{$\begin{array}{l}\text { ABO } \\
\text { Blood } \\
\text { Group }\end{array}$} & \multirow[t]{2}{*}{ HLA Haplotypes } & \multicolumn{2}{|c|}{$\begin{array}{l}\text { Child/Patient } \\
\text { Incompatibilities }\end{array}$} & \multirow[t]{2}{*}{$\begin{array}{l}\text { Case } \\
\text { No. }\end{array}$} & & \multirow{2}{*}{$\begin{array}{l}\text { ABO } \\
\text { Blood } \\
\text { Group }\end{array}$} & \multirow[t]{2}{*}{ HLA Haplotypes } & \multicolumn{2}{|c|}{$\begin{array}{l}\text { Child/Patient } \\
\text { Incompatibilities }\end{array}$} \\
\hline & & & & Locus $A$ & Locus B & & & & & Locus $A$ & Locus B \\
\hline 7 & $\begin{array}{l}\text { Husband } \\
\text { Patient } \\
\text { Child }\end{array}$ & $\begin{array}{l}\mathrm{O} \\
\mathrm{A} \\
\mathrm{O}\end{array}$ & $\begin{array}{l}\text { A3, BX/A2, BX } \\
\text { A } 1, \text { B8/AX, BW22 } \\
\text { A3, BX/A1, B8 }\end{array}$ & + & + & 351 & $\begin{array}{l}\text { Husband } \\
\text { Patient } \\
\text { Child }\end{array}$ & $\begin{array}{l}\mathbf{O} \\
\mathbf{O} \\
\mathbf{O}\end{array}$ & $\begin{array}{l}\text { A3, BW35/A2, B27 } \\
\text { AX, B12/A1, B7 } \\
\text { A3, BW35/AX, B12 }\end{array}$ & + & + \\
\hline 34 & $\begin{array}{l}\text { Husband } \\
\text { Patient } \\
\text { Child }\end{array}$ & $\begin{array}{l}\mathrm{O} \\
\mathrm{O} \\
\mathrm{O}\end{array}$ & $\begin{array}{l}\text { A2, B12/A1, B8 } \\
\text { A1, AX, B5, BW17 } \\
\text { A2, B12/A1, B? }\end{array}$ & + & + & 353 & $\begin{array}{l}\text { Husband } \\
\text { Patient } \\
\text { Child }\end{array}$ & $\begin{array}{l}\mathbf{O} \\
\mathbf{A} \\
\mathbf{O}\end{array}$ & $\begin{array}{l}\text { A11, B7/AW19, BX } \\
\text { A2, B14/AX, B12 } \\
\text { A11, B7/A2, B14 }\end{array}$ & + & + \\
\hline 56 & $\begin{array}{l}\text { Husband } \\
\text { Patient } \\
\text { Child }\end{array}$ & $\begin{array}{l}\mathrm{O} \\
\mathrm{A} \\
\mathrm{A}\end{array}$ & $\begin{array}{l}\text { AX, B12/A2, BX } \\
\text { A3, BX/A1, B8 } \\
\text { AX, B12/A3, BX }\end{array}$ & + & + & 366 & $\begin{array}{l}\text { Husband } \\
\text { Patient } \\
\text { Child }\end{array}$ & $\begin{array}{l}\mathbf{A} \\
\mathbf{O} \\
\mathbf{A}\end{array}$ & $\begin{array}{l}\text { A2, AX, B12, A17 } \\
\text { A2, B12/A28, B14 } \\
\text { A?, B12/A2, B12 }\end{array}$ & $?$ & - \\
\hline 63 & $\begin{array}{l}\text { Husband } \\
\text { Patient } \\
\text { Child }\end{array}$ & $\begin{array}{l}\mathrm{O} \\
\mathbf{A} \\
\mathbf{A}\end{array}$ & $\begin{array}{l}\text { A2, BW35/A1, B8 } \\
\text { A3, A29/B13, BW15 } \\
\text { A2, (BW35)/A3, B? }\end{array}$ & + & + & 421 & $\begin{array}{l}\text { Husband } \\
\text { Patient } \\
\text { Child }\end{array}$ & $\begin{array}{l}\mathbf{A B} \\
\mathbf{O} \\
\mathbf{A}\end{array}$ & $\begin{array}{l}\text { A2, B12/AW19, BX } \\
\text { A2, BX/A1, B7 } \\
\text { A2, B12/A2, BX }\end{array}$ & - & + \\
\hline 76 & $\begin{array}{l}\text { Husband } \\
\text { Patient } \\
\text { Child }\end{array}$ & $\begin{array}{l}\mathbf{A} \\
\mathbf{A} \\
\mathbf{A}\end{array}$ & $\begin{array}{l}\text { AX, B7/A2, BW40 } \\
\text { AX, B12/AW19, BW35( } \\
\text { AX, B7/AX, B12 }\end{array}$ & $5(+)$ & + & 428 & $\begin{array}{l}\text { Husband } \\
\text { Patient } \\
\text { Child }\end{array}$ & $\begin{array}{l}\mathrm{O} \\
\mathrm{O} \\
\mathrm{O}\end{array}$ & $\begin{array}{l}\text { A1, B8/A3, BW40 } \\
\text { A2, B12/AX, B5 } \\
\text { A1, B8/A2, B12 }\end{array}$ & + & + \\
\hline 82 & $\begin{array}{l}\text { Husband } \\
\text { Patient } \\
\text { Child }\end{array}$ & $\begin{array}{l}\mathrm{O} \\
\mathrm{A} \\
\mathrm{O}\end{array}$ & $\begin{array}{l}\text { A1, B8/A11, BX } \\
\text { A2, AX, BW } 21, \text { BW } 40 \\
\text { A1, B8/A2, B? }\end{array}$ & + & + & 432 & $\begin{array}{l}\text { Husband } \\
\text { Patient } \\
\text { Child }\end{array}$ & $\begin{array}{l}\mathbf{A} \\
\mathbf{B} \\
\mathbf{A B}\end{array}$ & $\begin{array}{l}\text { A2, B12/A9, BX } \\
\text { A9, B27/A } 1, \text { B12 } \\
\text { A2, B12/A9, B27 }\end{array}$ & + & - \\
\hline 101 & $\begin{array}{l}\text { Husband } \\
\text { Patient } \\
\text { Child }\end{array}$ & $\begin{array}{l}\mathrm{O} \\
\mathbf{A} \\
\mathbf{A}\end{array}$ & $\begin{array}{l}\text { AX, B7/A2, BX } \\
\text { A1, B8/A2, BX } \\
\text { AX, B7/A1, B8 }\end{array}$ & + & + & 437 & $\begin{array}{l}\text { Husband } \\
\text { Patient } \\
\text { Child }\end{array}$ & $\begin{array}{l}\mathbf{A} \\
\mathbf{O} \\
\mathrm{O}\end{array}$ & $\begin{array}{l}\text { A3, BX/AX, B8 } \\
\text { A2, B5/A10, B14 } \\
\text { A3, BX/A2, B5 }\end{array}$ & + & + \\
\hline 129 & $\begin{array}{l}\text { Husband } \\
\text { Patient } \\
\text { Child }\end{array}$ & $\begin{array}{l}\text { O } \\
\mathbf{A} \\
\mathbf{A}\end{array}$ & $\begin{array}{l}\text { A1, B8/AW19, B12 } \\
\text { A2, BX/AW19, BX } \\
\text { A1, B8/A2, BX }\end{array}$ & + & + & 441 & $\begin{array}{l}\text { Husband } \\
\text { Patient } \\
\text { Child }\end{array}$ & $\begin{array}{l}\mathbf{A} \\
\mathbf{O} \\
\mathbf{A}\end{array}$ & $\begin{array}{l}\text { A2, B13/A1, B8 } \\
\text { A3, B7/AX, B5 } \\
\text { A2, B13/A3, B7 }\end{array}$ & + & + \\
\hline 166 & $\begin{array}{l}\text { Husband } \\
\text { Patient } \\
\text { Child }\end{array}$ & $\begin{array}{l}\mathbf{O} \\
\mathbf{A} \\
\mathbf{A}\end{array}$ & $\begin{array}{l}\text { A3, BX/A1, B7 } \\
\text { A1, B8/A2, BX } \\
\text { AX, B7/A1, B8 }\end{array}$ & + & + & 448 & $\begin{array}{l}\text { Husband } \\
\text { Patient } \\
\text { Child }\end{array}$ & $\begin{array}{l}\mathbf{A} \\
\mathbf{A} \\
\mathbf{A}\end{array}$ & $\begin{array}{l}\text { A3, BW40/A29, B7 } \\
\text { A11, B18/A3, B7 } \\
\text { A3, BW40/A11, B18 }\end{array}$ & - & + \\
\hline 245 & $\begin{array}{l}\text { Husband } \\
\text { Patient } \\
\text { Child }\end{array}$ & $\begin{array}{l}\mathrm{O} \\
\mathrm{A} \\
\mathrm{O}\end{array}$ & $\begin{array}{l}\text { A1, B8/A3, BX } \\
\text { A1, BX/AX, BX } \\
\text { A1, B8/A?, BX }\end{array}$ & - & + & 463 & $\begin{array}{l}\text { Husband } \\
\text { Patient } \\
\text { Child }\end{array}$ & $\begin{array}{l}\text { O } \\
\mathbf{B} \\
\mathbf{O}\end{array}$ & $\begin{array}{l}\text { A2, AX, B5, B7 } \\
\text { A2, BW15/A10, B14 } \\
\text { A?, B7/A2, BW15 }\end{array}$ & $?$ & + \\
\hline 252 & $\begin{array}{l}\text { Husband } \\
\text { Patient } \\
\text { Child }\end{array}$ & $\begin{array}{l}\mathrm{O} \\
\mathrm{B} \\
\mathrm{O}\end{array}$ & $\begin{array}{l}\text { A } ?, \text { B14/AW19, BW35 } \\
\text { AW19, BX/A2, BX } \\
\text { A?, B14/AW19, BX }\end{array}$ & $?$ & + & 467 & $\begin{array}{l}\text { Husband } \\
\text { Patient } \\
\text { Child }\end{array}$ & $\begin{array}{l}\mathrm{O} \\
\mathrm{O} \\
\mathrm{O}\end{array}$ & $\begin{array}{l}\text { A1, B12/A2, B27 } \\
\text { A3, B7/A11, BW35 } \\
\text { A1, B12/A3, B7 }\end{array}$ & + & + \\
\hline 254 & $\begin{array}{l}\text { Husband } \\
\text { Patient } \\
\text { Child }\end{array}$ & $\begin{array}{l}\mathrm{O} \\
\mathrm{A} \\
\mathrm{O}\end{array}$ & $\begin{array}{l}\text { A9, B27/A3, BX } \\
\text { A1, BX/A3, B7 } \\
\text { A9, B27/A1, BX }\end{array}$ & + & 4 & 468 & $\begin{array}{l}\text { Husband } \\
\text { Patient } \\
\text { Child }\end{array}$ & $\begin{array}{l}\mathbf{A} \\
\mathbf{O} \\
\mathbf{A}\end{array}$ & $\begin{array}{l}\text { A11, B7/A1, B12 } \\
\text { A1, B7/A28, BW22 } \\
\text { A11, B7/A1, B7 }\end{array}$ & + & + \\
\hline 257 & $\begin{array}{l}\text { Husband } \\
\text { Patient } \\
\text { Child }\end{array}$ & $\begin{array}{l}\mathbf{O} \\
\mathbf{A} \\
\mathbf{A}\end{array}$ & $\begin{array}{l}\mathrm{A} 2, \mathrm{BX} / \mathrm{AX}, \mathrm{B} 8 \\
\mathrm{~A} 11, \mathrm{~B} 12 / \mathrm{A} 2, \mathrm{BX} \\
\mathrm{A} 2, \mathrm{BX} / \mathrm{A} 11, \mathrm{~B} 12\end{array}$ & - & $(+)$ & 472 & $\begin{array}{l}\text { Husband } \\
\text { Patient } \\
\text { Child }\end{array}$ & $\begin{array}{l}\mathbf{A} \\
\mathbf{O} \\
\mathbf{A}\end{array}$ & $\begin{array}{l}\text { A2, B17/A11, B27 } \\
\text { A9, A1, B17, BX } \\
\text { A2, B17/A9, B? }\end{array}$ & + & - \\
\hline 258 & $\begin{array}{l}\text { Husband } \\
\text { Patient } \\
\text { Child }\end{array}$ & $\begin{array}{l}\mathrm{A} \\
\mathrm{O} \\
\mathrm{O}\end{array}$ & $\begin{array}{l}\text { A1, B8/A9, BX } \\
\text { AW19, BX/A9, B27 } \\
\text { A 1, B8/AW19, BX }\end{array}$ & + & + & 476 & $\begin{array}{l}\text { Husband } \\
\text { Patient } \\
\text { Child }\end{array}$ & $\begin{array}{l}\mathbf{A} \\
\mathbf{O} \\
\mathbf{O}\end{array}$ & $\begin{array}{l}\text { A2, B7/AW19, B5 } \\
\text { A1, B8/A9, BW15 } \\
\text { A2, B7/A1, B8 }\end{array}$ & + & + \\
\hline 264 & $\begin{array}{l}\text { Husband } \\
\text { Patient } \\
\text { Child }\end{array}$ & $\begin{array}{l}\mathrm{O} \\
\mathbf{A} \\
\mathrm{A}\end{array}$ & $\begin{array}{l}\text { A2, B5/A3, B7 } \\
\text { AW19, B12/A2, B7 } \\
\text { A2, B5/AW19, B12 }\end{array}$ & - & + & 510 & $\begin{array}{l}\text { Husband } \\
\text { Patient } \\
\text { Child }\end{array}$ & $\begin{array}{l}\mathbf{O} \\
\mathbf{O} \\
\mathbf{O}\end{array}$ & $\begin{array}{l}\text { A9, BW21/A1, B8 } \\
\text { A11, B5/AW19, B7 } \\
\text { A9, BW21/A11, B5 }\end{array}$ & + & + \\
\hline 269 & $\begin{array}{l}\text { Husband } \\
\text { Patient } \\
\text { Child }\end{array}$ & $\begin{array}{l}\mathbf{B} \\
\mathbf{A} \\
\mathbf{O}\end{array}$ & $\begin{array}{l}\text { A9, BX/A2, BX } \\
\text { A1, B8/A9, B12 } \\
\text { A9, BX/A1, B8 }\end{array}$ & - & + & 515 & $\begin{array}{l}\text { Husband } \\
\text { Patient } \\
\text { Child }\end{array}$ & $\begin{array}{l}\mathbf{A} \\
\mathbf{O} \\
\mathbf{O}\end{array}$ & $\begin{array}{l}\text { A1, B8/A2, BX } \\
\text { A2, B17/A9, BW40 } \\
\text { A1, B8/A2, B17 }\end{array}$ & + & + \\
\hline 280 & $\begin{array}{l}\text { Husband } \\
\text { Patient } \\
\text { Child }\end{array}$ & $\begin{array}{l}\mathrm{O} \\
\mathrm{A} \\
\mathrm{O}\end{array}$ & $\begin{array}{l}\text { AX, B7/A1, BX } \\
\text { AW 19, BX/A9, B13 } \\
\text { AX, B7/AW19, BX }\end{array}$ & + & + & 530 & $\begin{array}{l}\text { Husband } \\
\text { Patient } \\
\text { Child }\end{array}$ & $\begin{array}{l}\mathbf{O} \\
\mathbf{A} \\
\mathbf{A}\end{array}$ & $\begin{array}{l}\text { A1, B8/A3, B7 } \\
\text { A11, B18/A28, B12 } \\
\text { A1, B8/A11, B18 }\end{array}$ & + & + \\
\hline 286 & $\begin{array}{l}\text { Husband } \\
\text { Patient } \\
\text { Child }\end{array}$ & $\begin{array}{l}\text { A } \\
\mathbf{B} \\
\mathbf{A B}\end{array}$ & $\begin{array}{l}\text { AX, BX/A2, B12 } \\
\text { A1, B8/AX, BW15 } \\
\text { AX, BX/A1, B8 }\end{array}$ & $(+)$ & + & & & & & & \\
\hline 294 & $\begin{array}{l}\text { Husband } \\
\text { Patient } \\
\text { Child }\end{array}$ & $\begin{array}{l}\mathbf{A} \\
\mathbf{O} \\
\mathbf{A}\end{array}$ & $\begin{array}{l}\text { A2, B12/A1, B8 } \\
\text { A9, A2, B12, BX } \\
\text { A2, B12/A } 9, \text { BX or } 12\end{array}$ & - & - & & & & & & \\
\hline
\end{tabular}

Table III HLA data on the antecedent child and husband of each of 36 patients in whom choriocarcinoma followed a live term birth

been transfused. Thus it can be concluded that HLA antibodies, if formed, result from the immunogenic stimulation of the antecedent pregnancy in patients who subsequently develop choriocarcinoma.

The same approach can also be used to show which pregnancy was likely to be associated with the malignancy in patients with complicated obstetric histories. For example, case 487 was admitted for treatment following a diagnosis of secondary choriocarcinoma in a vaginal nodule. Irregular 


\begin{tabular}{lll}
\hline Parity & $\begin{array}{l}\text { Antibody against Cells of Husband and } \\
\text { Donor Panel }\end{array}$ \\
\cline { 2 - 3 } & + & - \\
\hline Multiparous & 12 & 5 \\
Primiparous & $6+1^{1}$ & 1 \\
\hline
\end{tabular}

Table IV HLA Antibodies in 25 patients with choriocarcinoma following a live-term birth

${ }^{1}$ Maternal serum gave negative cytotoxic reaction with cells of child.

menstruation had followed the last normal term birth in 1972. In 1970 the patient had had a hydatidiform mole and in 1968 a normal term birth. The HLA types of the family were as follows:

\begin{tabular}{ll}
\hline Husband & A29, B12/A3, B27 \\
Patient & A29, B12/A2, B18 \\
Male born 1968 & A29, B12/A29, B12 \\
Male born 1972 & A29, B12/A2, B18 \\
\hline
\end{tabular}

The patient's serum contained anti-B27 antibody which would not have been produced as a result of immunization by either of the children because neither had inherited the appropriate haplotype from the father. The presence of theanti-B27 antibody could be accounted for by another conceptus following the birth of the youngest male or by the persistence of trophoblast from the pregnancy with the hydatidiform mole between the liveborn children.

It is known that in rare instances choriocarcinoma may occur many years after the last possible pregnancy, for example, in a hysterectomized patient (Lawler et al, 1976). In this context it is interesting to note the possible relevance of the persistence of trophoblast from a previous pregnancy in the aetiology of spina bifida and anencephaly (Knox, 1974; Clarke et al, 1975).

\section{HLA Antigens and Trophoblastic Disease}

Evidence of associations between various diseases of the HLA system continues to accumulate and several groups of workers have looked for effects related to trophoblastic disease (Ivašková et al, 1968; Amiel and Lebovici, 1970; Rudolph and Thomas, 1970; Lawler et al, 1971; Lewis and Terasaki, 1971; Mogensen and Kissmeyer-Nielsen, 1972; Mittal et al, 1975).

One of the problems which besets this type of study is the definition of disease entity in the different clinical groups. In the studies done in my laboratory in collaboration with Professor K. D. Bagshawe we have used the following criteria: the patients in whom persistence of trophoblastic disease followed term birth or nonmolar abortions are regarded as cases of choriocarcinoma even in the absence of histological evidence. On the other hand, following a molar pregnancy the diagnosis of choriocarcinoma is not made in the absence of histological proof. Patients with a history of hydatidiform mole who require treatment for persistence of trophoblastic tissue have been classified as 'treated moles'.

The first question which can be asked is whether patients with trophoblastic disease show any disturbance in the distribution of HLA antigens. In a study of 100 cases, 51 of choriocarcinoma and 49 of 'treated moles', typed between 1969 and 1972, Klouda (1975) found no statistically significant difference from the frequency found in normal controls of the antigens in the patients nor in 93 of their husbands who were available for testing.

The fact that the frequencies of the HLA A and B locus antigens in the patients and their husbands do not differ significantly from that found in normal controls does not preclude the possibility that certain antigenic combinations between husband and wife might constitute a risk factor to the patient. If this were the case one would expect to find that the matings were not random. In a study of HLA mating analysed separately for the A and B locus antigens the frequency of the different mating types was found to be as expected on the basis of the antigenic frequencies actually observed in the patients and their husbands (Klouda et al, 1972). Thus, as far as these antigens are concerned, mating was at random. The risk of a woman getting trophoblastic disease is apparently not influenced by her choice of mate as far as the HLA antigens are concerned.

Another way of looking at the problem is to see whether there is a tendency for the patients to be more or less compatibly mated than normal control couples. It has been shown that HLA incompatibility scores between husbands and patients with trophoblastic diseases do not differ significantly from those of controls (Lawler et al, 1971). Furthermore an analysis of the different clinical groups also revealed no difference between them as far as A and B locus incompatibility was concerned (Klouda, 1975).

Because of the isogenicity of tumour and child the patients in whom the question of genetic effects can be most closely studied are those in whom choriocarcinoma followed live term birth. A child can be incompatible with the mother for one A locus allele and one B locus allele. In the majority of cases scoring for incompatibilities is straightforward. However, difficulties arise when all the specificities cannot be defined. When the child inherits the haplotype with an undefined specificity from the father, and the mother also has only one allele defined at that locus, if the mother were homozygous 
the child would be incompatible (scored $(+)$, for example, case 286 locus A, case 257 locus B). On the other hand, if a specificity is not defined in the child because of homozygosity in some situations that child would be compatible with the mother (scored ? for example, 366-locus A). The child/patient incompatibilities scored are given in table V. By reference also to table III it can be seen that choriocarcinoma can supervene in the presence of HLA incompatibility for a wide spectrum of $\mathbf{A}$ and $\mathbf{B}$ locus antigens. Two-thirds of the offspring were incompatible with the mother at both loci. Only two of the offspring were compatible with the mother at both loci (294 and 366, table III). It has been estimated that in normal single child families in the United Kingdom, $24 \%$ would be expected to be compatible for one antigen (choriocarcinoma families $27 \%$ ) and $2 \%$ of families would be expected to be compatible at both loci (choriocarcinoma $6 \%$ ). Thus it is apparent that the development of choriocarcinoma is not preferentially associated with conceptuses compatible with the mother. It is a point of considerable interest that both children that were HLA compatible with the mother were ABO incompatible.

\begin{tabular}{lll}
\hline \multicolumn{2}{l}{ Child/Patient Incompatibilities $^{1}$} & \\
\hline Locus & & \\
\hline$A$ & $B$ & Number of Cases \\
\hline+ & + & 22 \\
$(+)$ & + & 2 \\
+ & + & 5 \\
+ & + & 2 \\
$?$ & $(+)$ & 1 \\
- & - & 1 \\
- & - & 1 \\
\hline
\end{tabular}

Table V Thirty-six patients with choriocarcinoma following term birth 1959-1974

$1+=$ incompatible, $(+)=$ probably incompatible, $?=$ probably compatible, $-=$ compatible.

\section{The ABO System and Trophoblastic Disease}

In marked contrast to the absence of effect with the HLA system is the relationship to the ABO system. It has been shown that in a Caucasian population an increased risk of choriocarcinoma for group A women, as compared with group $\mathrm{O}$, is dependent on the ABO group of the husband. The relative risk for group $A$ women with group $O$ husbands as compared with group A with group A husbands was 10.4/1 (Bagshawe et al, 1971). Recently, Bagshawe (1976) has extended the analysis and found that the risk of group $\mathbf{O}$ women developing a choriocarcinoma also relates to the group of the husband, greater risk being associated with group $A$ husbands. The observations up to this point could be explained by immunological reaction involving fetal recognition of the maternal tissue as foreign. Difficulties arise, however, when the ABO groups of the children antecedent to the choriocarcinoma are studied. In both the high risk mating types female $\mathrm{A} \times$ male $\mathrm{O}$ and female $\mathbf{O} \times$ male $\mathbf{A}$ the segregation of the children was not disturbed so there was no tendency to produce only offspring with a phenotype incompatible to the mother (Bagshawe, 1976). This means that the risk depends not on the genotype of the child isogenic with the tumour but on the phenotype of the spouse.

As has been pointed out already, the evidence based on immunization to HLA antigens favours the contention of isogenicity of host and tumour when choriocarcinoma follows live term birth. It is difficult to explain an effect dependent on nonrandom mating that is not related to the genotype of the child at the relevant locus. An explanation may have to be sought very early, possibly at fertilization, where products carried by or accompanying the sperm that fuses with the oocyte have some influence on future trophoblastic development.

The idea of non-Mendelian transmission of genetic information into the nuclei of cells in the female genital tract is a possibility that might be considered in this context. The rapid disappearance of excess spermatozoa in the female has been attributed to phagocytosis and subsequent drainage through the cervix (Yanagimachi and Chang, 1963). On the other hand, Reid (1965) showed that stromal cells regenerating after injury to the mouse uterine mucosa took up radioactively labelled spermatozoa, sometimes with the spermatozoa enveloped in a fold of the stromal nucleus. So the possibility of the total genotype of the male being effective through some mechanism involving an intranuclear event between sperm and female genital tract cells cannot be excluded.

\section{Cellular Reaction}

It has been suggested that the infiltration of mononuclear cells in gestational choriocarcinoma is a response to tumour antigens (Elston and Bagshawe, 1973). Such a reaction could also reflect the histocompatibility differences between tumour and host, since the evidence presented in this paper favours the idea that trophoblastic tumours express HLA specificities. Elston and Bagshawe (1973) regard the effect of mononuclear infiltration as favourable to prognosis because the infiltration contributes to tumour death by mounting an immunological 
response directed at tumour rejection. If cell division contributes to the efficiency of this response then certain factors involved in the fetomaternal relationship may be relevant. It has been shown that although maternal lymphocytes can recognize and respond to neonatal lymphocytes in a one-way mixed lymphocyte culture in which the neonatal cells are not viable, when both populations are living, the mitosis of maternal cells is inhibited (Lawler et al, 1975). A failure of mononuclear infiltration round a choriocarcinoma to be associated with a good prognosis could be due to the inhibition of mitotic activity of host cells in the presence of viable tumour cells. These factors, which may be regarded as a carry-over of normal biological effect, could be reinforced if the patient's immune responses are also generally depressed.

\section{Conclusions}

The HLA system has given an insight into the general question of the immunogenic activity of trophoblast. Evidence that a single pregnancy with a hydatidiform mole can provoke HLA antibody formation suggests that trophoblastic cells or their products are immunizing agents which could also be operative in normal pregnancies. As far as choriocarcinoma is concerned there is no clear-cut evidence to impute a role to the HLA system amongst the risk factors. The choice of mate in relation to the HLA system appears not to influence a woman's chance of developing a choriocarcinoma. However, a detailed analysis of the system amongst the different clinical groups has yet to be made when the number of cases studied is sufficient. Another factor which must be considered is whether there is any difference in prognosis for responders and nonresponders as defined by a capacity to make HLA antibodies is concerned. The D locus factors also present an area for further study, but the genetic disequilibrium in the HLA system decreases the chance of finding genetic associations with $\mathrm{D}$ locus factors if none have been shown with studies restricted to the A and B loci. Furthermore, the response of the patient in the mixed lymphocyte culture test in relation to her offspring is influenced by the immunological effects of pregnancy.

The ABO system also presents a fruitful area for further study of risk and prognostic factors in choriocarcinoma. It would be of interest to have data on secretor status. The relevance of the Atri system (Marcelli-Barge et al, 1975) might also be considered since this is an antigen expressed on the lymphocytes of $5 \%$ of group A ABH secretors. Since risk factors depend on the phenotype of the male and not the genotype of the conceptus con- sideration might be given to the possibility of an effect mediated by integration of nuclear elements in the sperm with female genital tract cells.

The most interesting question still remains unanswered: What makes the trophoblast become malignant? This problem could be approached by attempting to define differences between choriocarcinoma supervening after molar or non-molar pregnancies and by ascertaining which molar pregnancies have a malignant potential.

I am indebted to Professor K. D. Bagshawe for his collaboration and to Sister Joan Dent for clinical details and collection of samples. I should like to thank the former member, Dr P. T. Klouda, and present members of my department, Mrs Ivanka Mrazek and Miss Sushama Singh, for their participation in these studies.

\section{References}

Adenolfi, M. (1975). The human placenta as a filter for cells and plasma proteins. In Immunobiology of Trophoblast, edited by R. G. Edwards, C. W. S. Howe, and M. H. Johnson, pp. 193-215. Cambridge University Press, Cambridge.

Alberman, E., Elliott, M., Creasy, M., and Dhadial, R. (1975). Previous reproductive history in mothers presenting with spontaneous abortions. Brit. J. Obstet. Gynaec., 82, 366-373.

Amiel, J. L., and Lebovici, S. (1970). Choriocarcinoma and the HL-A2 antigen (MAC). Rev. Europ. Étud. clin. biol., 15, 191-192.

Amos, D. B. (1974). HL-A, fertility and natural selection. In Immunological Approaches to Fertility Control, Karolinska Symposia on Research Methods in Reproductive Endocrinology, no. 7) edited by E. Diczfalusy, pp. 318-335. Karolinska Institut, Stockholm.

Bagshawe, K. D. (1976). Risk and prognostic factors in trophoblastic neoplasia. Cancer Res., in press.

Bagshawe, K. D., Rawlins, G., Pike, M. C., and Lawler, S. D. (1971). ABO blood-groups in trophoblastic neoplasia. Lancet, 1, 553-557.

Bodmer, J. (1973). Personal communication.

Boué, J. G., Boué, A., Lazar, P., and Gueguen, S. (1973). Outcome of pregnancies following a spontaneous abortion with chromosomal anomalies. Amer. J. Obstet. Gynec., 116, 806-812.

Clarke, C., Hobson, D., McKendrick, O. M., Rogers, S. C., and Sheppard, P. M. (1975). Spina bifida and anencephaly: miscarriage as possible cause. Brit. med. J., 4, 743-746.

Edwards, R. G., Ferguson, L. C., and Coombs, R. R. A. (1964). Blood group antigens on human spermatozoa. J. Reprod. Fertil., 7, 153-161.

Edwards, R. G., Howe, C. W. S., and Johnson, M. H. Eds. (1975). Immunobiology of Trophoblast. Cambridge University Press, Cambridge.

Elston, C. W., and Bagshawe, K. D. (1973). Cellular reaction in trophoblastic tumours. Brit. J. Cancer, 28, 245-256.

Fellous, M., and Dausset, J. (1970). Probable haploid expression of HL-A antigens on human spermatozoon. Nature (Lond.), 225, 191-193.

Gullbring, B. (1957). Investigation on the occurrence of blood group antigens in spermatozoa from man, and serological demonstration of the segregation of characters. 
Acta med. scand., 159, 169-172.

Halim, A., Abbasi, K., and Festenstein, H. (1974). The expression of the HL-A antigens on human spermatozoa. Tissue Antigens, 4, 1-6.

Halim, K., and Festenstein, H. (1975). HLA-D on sperm is haploid, enabling use of sperm for HLA-D typing. (Letter). Lancet, 2, 1255-1256.

Histocompatibility Testing, 1975, edited by F. KissmeyerNielsen. Munksgaard, Copenhagen.

Ivašková, E., Jakoubková, J., Zavadil, M., Schneid, V., Koldovský, P., and Iványi, P. (1968). HL-A antigens and the choriocarcinoma. Folia biol. (Praha), 14, 398-401.

Kerék, G. (1974). Distribution of the blood group antigens A and B on human spermatozoa. Int.J. Fertil., 19, 181-191.

Klouda, P. T. (1975). The HL-A system: genetics and application to the study of a malignant disease. PhD Thesis, University of London.

Klouda, P. T., Lawler, S. D., and Bagshawe, K. D. (1972) HL-A matings in trophoblastic neoplasia. Tissue Antigens, 2, 280-284.

Knox, E. G. (1974). Twins and neural tube defects. Brit J. prev. soc. Med, 28, 73-80.

Landsteiner, K., and Levine, P. (1926). Group specific substances in spermatozoa. J. Immunol., 12, 415-418.

Lauritsen, J. G., Grunnet, N., and Jensen, O. M. (1975). Materno-fetal ABO incompatibility as a cause of spontaneous abortion. Clin. Genet., 7, 308-316.

Lawler, S. D. (1973). The significance of HL-A antibodies in trophoblastic neoplasia. In Immunology in Obstetrics and Gynaecology: Proceedings of the 1st International Congress (International Congress Series No. 327), edited by A. Centaro, and N. Carretti, pp. 310-311. Excerpta Medica, Amsterdam.

Lawler, S. D., Klouda, P. T., and Bagshawe, K. D. (1971). The HL-A system in trophoblastic neoplasia. Lancet, 2 , 834-837.

Lawler, S. D., Klouda, P. T., and Bagshawe, K. D. (1976). The relationship between HLA antibodies and the causal pregnancy in choriocarcinoma. Brit., J. Obstet. Gynaec., in press.

Lawler, S. D., Ukaejiofo, E. O., and Reeves, B. R. (1975). Interaction of maternal and neonatal cells in mixedlymphocyte cultures. Lancet, 2, 1185-1187.

Levine, P. (1943). Serological factors as possible causes in spontaneous abortions. J. Hered., 34, 71-80.

Levis, W. R., Whalen, J. J., and Sherins, R. J. (1974). Sperminduced lymphocyte transformation. (Letter). Lancet, 2, 954-955.

Lewis, J. L., Jr., and Terasaki, P. I. (1971). HL-A leukocyte antigen studies in women with gestational trophoblastic neoplasms. Amer. J. Obstet. Gynec., 111, 547-554.

Loke, Y. W., Joysey, V. C., and Borland, R. (1971). HL-A antigens on human trophoblast cells. Nature (Lond.), 232, 403-405.

Marcelli-Barge, A., Poirer, J. C., Benajam, A., and Dausset, J. (1976). A lymphocyte immunogenetic system, Atri, associated with the $\mathrm{ABO}$ blood group and the $\mathrm{ABH}$ secretor system. Vox Sang. (Basel), 30, 81-90.

Mittal, K. K., Kachru, R. B., and Brewer, J. I. (1975). The HL-A and ABO antigens in trophoblastic disease. Tissue Antigens, 6, 57-69.

Mogensen, B., and Kissmeyer-Nielsen, F. (1972). Invasive mole, gestational choriocarcinoma and transplantation antigens. Ser. Haemat., 5 (5), 22-43.

Reid, B. L. (1965). Interaction between homologous sperm and somatic cells of the uterus and peritoneum in the mouse. Exp. Cell Res., 40, 679-683.

Rudolph, R. H., and Thomas, E. D. (1970). Histocompatibility studies in patients with trophoblastic tumors. Amer. J. Obstet. Gynec., 108, 1126-1129.

Sachs, D. H., and Cone, J. L. (1973). A mouse B-cell alloantigen determined by gene(s) linked to the major histocompatibility complex.J. exp. Med., 138, 1289-1304.

Yanagimachi, R., and Chang, M. C. (1963). Infiltration o leucocytes into the uterine lumen of the golden hamster during the oestrous cycle and following mating. J. Reprod. Fertil., 5, 389-396. 